\title{
Political Rhetoric and Hate Speech in the Case of Shamima Begum
}

\author{
Alexander Murphy
}

check for updates

Citation: Murphy, Alexander. 2021. Political Rhetoric and Hate Speech in the Case of Shamima Begum. Religions 12: 834. https://doi.org/ 10.3390/rel12100834

Academic Editors: Chris Allen,

Christina Verousi and

Klaus Baumann

Received: 13 August 2021

Accepted: 25 September 2021

Published: 8 October 2021

Publisher's Note: MDPI stays neutral with regard to jurisdictional claims in published maps and institutional affiliations.

Copyright: (C) 2021 by the author. Licensee MDPI, Basel, Switzerland. This article is an open access article distributed under the terms and conditions of the Creative Commons Attribution (CC BY) license (https:// creativecommons.org/licenses/by/ $4.0 /)$.
School of Criminology, University of Leicester, Leicester LE1 7RH, UK; am1058@leicester.ac.uk

\begin{abstract}
The relationship between political rhetoric and hate crime has been a topic of growing concern in recent years, with the narratives promoted by politicians widely seen as legitimating and inspiring hate crime as well as soothing or inflaming the tensions that result from antecedent hate crime events such as terrorist attacks. The potential return of so-called 'IS bride' Shamima Begum from a Syrian refugee camp in 2019, following her high-profile departure four years earlier, led to intense debate within the UK, particularly over the controversial removal of her citizenship by Home Secretary Sajid Javid. As an Islamist terrorism case with clear gendered dimensions, the Begum case was well-positioned to function as a hate crime trigger event. The divisiveness of this case was reflected in partisan political argument within the UK, and accompanied by high volumes of toxic and Islamophobic social media discussion alongside input from a variety of UK politicians. This paper offers a qualitative analysis of the political rhetoric promoted in the Twitter accounts of leading UK politicians in response to the citizenship decision, and subsequent developments between February and April 2019, such as the death of Begum's child and the granting of legal aid to support her ongoing legal challenge. Through a Critical Discourse Analysis of politicians' online rhetoric, this study aims to establish the contribution of UK political rhetoric to the hate speech discourses that emerged online in response to this case.
\end{abstract}

Keywords: terrorism; Islamophobia; political rhetoric; hate speech; trigger events; Shamima Begum

\section{Introduction}

Hate crime is an issue that has risen up the political agenda in recent years, with police recorded rates demonstrating consistent yearly increases in the UK and reaching record level in 2020 (Home Office 2020). Within this context, dramatic spikes in hate crime have routinely accompanied trigger events such as terrorist attacks or the EU referendum result (Devine 2021; O'Neill 2017; Piatkowska and Stults 2021), or the protests and counterprotests that followed the death of George Floyd in the summer of 2020 (Home Office 2020), as pre-existing social tensions simmer over in response to perceived out-group provocations. Political commentary is a prominent part of the reaction to antecedent hate crime events, and offers an opportunity for leaders to inflame or mitigate social tensions as well as promote their preferred narratives. Racial and religious dimensions are particularly susceptible to being whipped up or alleviated in the aftermaths of these events. While religious hate crime declined by 5\% in the UK's 2020 official figures, Islamophobic hate crime made up 50\% of the total, with Muslims the most likely demographic group to be the victims, and they are the routine targets of concerted backlash following terrorist incidents (Home Office 2020).

Contemporary shifts in political culture across much of the Western world have led to renewed scrutiny on the potentially disruptive influence of exclusionary rhetoric, and a growing body of work indicates a direct connection between the words utilised by political leaders and the incidents of hate crime that affect marginalised groups internationally (Levin 2016; Müller and Schwarz 2020). This work builds on prior evidence on the effects of political messaging on vulnerable groups, with reports of disability hate crime rising 
$53 \%$ in the year to 2016/17 ( $\mathrm{O}^{\prime} \mathrm{Neill} 2017$ ), for example. Qualitative evidence suggested an increase in the use of epithets such as 'scrounger' amidst the relentless focus on benefits cuts and economic deservingness that characterised successive Conservative-led governments' austerity agendas (Quarmby 2012). Despite ostensibly inclusive governmental rhetoric on issues of disability and inclusion, policy which characterised disabled benefits claimants as dependent and requiring incentivisation to work shaped perceptions (Healy 2020), fuelling negativity, marginalisation, and victimisation.

In this way, political culture has long been understood to affect hate crime discourses, but establishing a causal impact from any particular instance of rhetoric is problematic given the mix of influences involved in provoking or allaying a hate crime offender. Burnett (2017) has argued that hate crimes explicitly reflect dominant ideological positions, reflecting the internalisation of cultural discourses. While the link between Boris Johnson's dismissive allusion to veiled women as resembling 'letterboxes' and the subsequent use of the term as an Islamophobic insult appears obvious (see Bienkov 2019), the precise relationship between Donald Trump's demand on Twitter that four non-white (and US-born, bar one) congresswomen 'go back and help fix the totally broken and crime infested places from which they came' (Trump 2019) and any ensuing instances of racist hate crime is difficult to determine, despite the tweets' evident racist charge and the status of its author.

Shifts in technology have clearly revolutionised the ways in which politicians communicate with the public, with regular commentary expected of leading politicians and the historic gatekeepers of the press and broadcast media more easily bypassed nowadays via social media outreach (Jungherr 2016; Parmelee and Bichard 2012). Leadership rhetoric plays an established role in setting agendas and influencing public moods (Oliver et al. 2011; Stuckey 2015), while the effective tailoring of these messages to audience, medium, and context has been a subject of study and debate for centuries (Knudsen 2014), and is as pressing for modern politicians on Twitter as in any other era. The ease with which a politician can autonomously broadcast to followers around the world, and the propensity for messages to endure and recirculate once released, is nonetheless a major shift. Subsequently, the notion that a politician's rhetoric might endanger their public, or reinforce harmful narratives, is a matter of public concern given the clear accountability that political figures have to their citizens. The circulation of hate speech and misinformation on social media sites, and the role played by prominent elected politicians, have subsequently left social media organisations scrambling to adapt, with technical efforts to weed out hate speech and enforce laws and community standards criticised for their appropriateness, inconsistency, and inadequacy (see Balica 2017; Gagliardone et al. 2015; Hern 2020). This attracted opprobrium from both sides of the aisle in the aftermath of the 2020 US Presidential election (Kelion 2020), with controversy surrounding the removal of the social network Parler from hosting services (Novet 2021) as well as the deplatforming of the former president himself from mainstream social media outlets (Conger and Isaac 2021). Both online and offline hate incidents spike dramatically in the aftermaths of trigger events, with well-evidenced harms for the dignity and security of victims and society (see Brown 2017; Gelber and McNamara 2016; Waldron 2012; Williams et al. 2020). Nonetheless, the political dimensions of these online discourses remain comparatively underexplored, as does the role played by political rhetoric. As a high-profile new story, featuring divisive aspects concerning terrorism, race, religion, and gender, the experience and potential return of so-called 'IS bride' Shamima Begum was a promising antecedent hate crime event in relation to which UK political rhetoric could be evaluated.

The particularly outcry that accompanied this case in the UK requires some context. In 2015, British teenagers Shamima Begum, Kadiza Sultana, and Amira Abase left their homes in Bethnal Green and made their way to Syria via Turkey, funding the trip by selling stolen family jewellery. Their aim was to support the Islamic State group (then near its peak of territory and influence) and ultimately serve as brides to foreign IS recruits (Sherlock et al. 2015). Begum was fifteen at the time, and contemporary media accounts generally mixed concern about the girls' wellbeing with recriminations over their apparent 
radicalisation and the ease with which they appeared to have reached the Caliphate (BBC 2015). Begum's re-emergence in 2019, following years of IS atrocities and the collapse of the Caliphate at the hands of a multinational alliance, evoked an entirely different response. After Begum was discovered by journalists, pregnant and residing in a Syrian refugee camp, she gave a number of interviews in which she expressed no remorse for IS victims in Syria or the UK or any regret for joining IS, and stated her wish to return to the UK (BBC 2019b). Public backlash was striking and immediate, with then Home Secretary Sajid Javid publicly announcing the loss of her citizenship, a move which was extremely controversial, particularly in light of the subsequent death of Begum's baby in the unsanitary conditions of the al-Hawl refugee camp (Doward et al. 2019). A Sky Data poll in February 2019 found that 78\% of Britons supported the removal of her citizenship (Carr 2019), while thinkpieces on all sides of the argument (see Dejevsky 2019; Morgan 2019; Wallis 2019) dominated press coverage and fanned vitriolic social media debate over Begum's rights and the UK's responsibilities. Given the terrorist connection, gendered dimension, and politicised public backlash, the Begum case was an obvious potential antecedent hate crime event. Relevant tweets from nineteen selected UK politicians were subsequently gathered in relation to various developments in the case between February and April 2019, namely, the removal of Begum's citizenship, her relocation to a new camp following threats, a plea for clemency from her father, the subsequent death of her baby, and the decision to grant Begum legal aid to appeal the citizenship ruling.

This article intends to unpick the political discourses promoted on Twitter by leading UK politicians in the wake of a number of developments in the controversial terrorism and citizenship case of Shamima Begum, highlighting a relative lack of commentary from mainstream politicians, despite the public salience of the case. The limited pool of politicians to have intervened are nonetheless rhetorically brutal, with those on the left targeting the perceived inhumanity of the government and Home Secretary, while figures from the right-wing UKIP fringe focus on denouncing terrorism and-by rhetorical extension-Islam itself in often bitter and Islamophobic terms. In particular, this article will address the following research question:

- What language and themes are used in the rhetoric of contemporary UK politicians in response to the Shamima Begum citizenship controversy?

\section{In Context}

This study relates to conceptual work on the social context surrounding hate crime, the role that political rhetoric plays, and the impact of antecedent events in legitimising hostile narratives. It contributes to a body of work on the power of rhetoric, and intends to delineate the discourses disseminated by UK politicians in relation to the Shamima Begum case.

The links between the political and social context and hate crime are well-known. In addition to the stigmatising effects of austerity economics for disabled and other 'undeserving' groups (Briant et al. 2013; Chakraborti and Garland 2015; Healy 2020), hate crime rates were observed to escalate over the course of a contentious EU referendum campaign in 2016, for example, with racial and religious victimisation spiking further in the aftermath of the result (with rates of racist hate crime 44\% higher in July 2016 than they were in the preceding July, and racist hate crime rising $27 \%$ overall in the year to 2016/17) $\left(\mathrm{O}^{\prime}\right.$ Neill 2017). The link between this more general context and the roles of trigger events is blurred, with the dramatic spikes that accompany trigger events drawing from narratives established over a much longer timeframe. The backlash to the referendum result, thus, reflected themes of the campaigns, which drew in turn from a history of British Euroscepticism and concern over immigration (for example) legitimised by successive governments and media sources over decades. These atmospheres of hostility have significant impacts on the lived experiences and prospects of new and established minority communities in the UK. The All Party Parliamentary Group on Social Integration (2017) viewed politicians as having failed in their duty to foster positive community relations through their rhetoric 
during the campaigns, and to have contributed historically to division through, for example, the representation of integration as a security issue, or the endless, disillusioning promotion of unachievable immigration targets. Indeed, evidence from Germany indicated that increased anti-immigrant hate crimes in the wake of recent waves of immigration varied significantly between regions, being up to six times higher in some regions than other, and generally higher in the east (Piatkowska et al. 2020). Immigration rates, social integration, youth unemployment, and general crime rates were associated with increased right-wing hate crime, with high immigration becoming a trigger only in the context of other factors, and the rhetorical suggestion of a 'refugee crisis' serving to instigate high levels of victimisation (Piatkowska et al. 2020). The role of politicians and the press in framing immigration as a threat is fundamental to this process.

Burnett (2017) viewed the post-referendum increases in racial violence as reflecting a hostile political environment embedded and reinforced over a much longer timespan than just the course of the campaigns. While most racist hate crimes recorded in the aftermath of the referendum were targeted at Muslims and (in particular Eastern) European migrants, incidents targeted towards black people, Jewish people, and those speaking foreign languages were also evident. Burnett indicates a number of themes that manifested in the detail of these offences and the words or behaviours used, in those cases where the referendum was not directly referenced. These included the idea that a historic wrong was being righted, and cultural norms re-established, as well as sentiment reflecting racist notions of entitlement. Voting or having campaigned for Remain was frequently viewed as a betrayal. Anti-migrant and Islamophobic racism were also frequently conflated, as the theme of the referendum had increasingly become about entitlement to be in the UK in a way that lent itself to established narratives depicting Muslims as 'societal antibodies', undermining the cultural basis of the nation (Burnett 2017, p. 89). This is placed in a context where political promotion of 'British values' had already suggested that Muslim status was 'antithetical to Britishness' (Burnett 2017, p. 89). Burnett is sharply critical of the assumption that a tolerant nation suddenly slipped into racial violence, pointing towards endless policy antecedents from successive governments (including debate over immigration numbers or moral panics about benefit scroungers) laying the groundwork for fringe political positions to become mainstream policies. Post-referendum violence should not be seen as a sudden spike, but as the result of policy decisions and a mistrustful climate that had previously served political purposes.

This analysis intersects with points made by Perry (2001) on how exclusionary rhetoric from the state may serve the purposes of government (with the state defined as encompassing politicians and all those whose work intersects with that of government, such as activists or lobbyists). Perry discusses how the state has to reflect and maintain prejudiced sentiment from its public in order to retain legitimacy, giving the example of how reactionary politics in the USA in the 1970s and 1980s had to be 'absorb[ed] and reflect[ed]' by the state in just the same way as the state had moved to support the Civil Rights movement several years earlier (Perry 2001, p. 185). She cites 'Gramsci's assertion that hegemony must begin with or incorporate prevailing sentiments' (Perry 2001, p. 183) and contrasts with Burnett, who views the actions of the state as responsible for inciting and maintaining an atmosphere of racial violence. The exact extent of the influence of the state in a particular occurrence of hate crime does, therefore, seem to invite some debate. Perry and Scrivens' (2018) notion of 'permission to hate' is a particularly instructive concept when considering the political economies of Islamophobia, and argues that hate and extremism require facilitating environments in order to grow. Extreme right and populist groups across much of the contemporary US and Europe are viewed as having asserted identity through the delineation and ostracisation of Others, particularly Muslims, and thus, created ecosystems that reinforce patterns of oppression and subjugation (Perry and Scrivens 2018). Racism and exclusion are historically normalised within societies, at the same time as political climates of intolerance (encompassing rhetoric, policy, legislation, and coercion) and an absence of effective sanction reinforce and legitimise these sentiments, thus bestowing 'per- 
mission to hate' to the wider public (Perry and Scrivens 2018, p. 176). Post-9/11 patterns of Islamophobic victimisation, for example the intersectional elements affecting Muslim women (Perry 2014), reflect these same processes of othering and political machination, and the influence of politicians over these brutal impacts is substantial.

It does seem inevitable that the words and actions of public influencers may reinforce prejudices at the very least, in cases where they do not directly inflame them. Politicians would seem to be bear particular responsibility for the messages they propagate. Aggressive rhetoric on Islam, immigration, or disability benefits circulates through the media, fits in with established narratives, and creates spaces in which bigotry and hate crime gain legitimacy. Lewis (2013) has parsed the rhetoric of US politicians in the wake of highly publicised hate crimes, observing that hate crimes are depicted as un-American, yet also as an assault on the state itself. One of these aspects keeps the unblemished state outside the offence, standing in condemnation, while the other paints the state as the real victim. These contradictory tropes recur time and again over the decades of vapid rhetorical responses to hate crime from US politicians, and offer no acknowledgement of the social issues that lead to such offences (Lewis 2013). This rhetoric has the state inserted within, and entirely detached from hate crime, and blocks any understanding of these offences as reflective of social reality. It may be politically expedient to place hate crimes outside mainstream politics and everyday social life, but this does not make such distancing any more convincing. At the same time, the stigmatisation of outgroups has a centuries-long track record of providing political advantage (Burnett 2017; Glaeser 2005), and exclusionary sentiment is routinely exploited, overtly or indirectly, by politicians worldwide in reference to immigrants, foreigners, and other social groups. The suggestion that political rhetoric directly instigates hate crime, then, as well as shaping its conditions, is intuitively convincing.

A number of methodological issues that have impeded attempts to connect the words of politicians with the actions of hate crime offenders. Hate crime causation is complex, with the victim, perpetrator, and society all playing roles that can be difficult to quantify or separate. There is evidence in support of various structural explanations for hate crime, such as the intended defence of communities and the perception of economic threat (Blalock 1960; Van Kesteren 2016; Walters 2011), as well as in more individualised psychological assessments of hate crime offenders' personalities and motivations (for example the offender typology offered by McDevitt et al. 2002). Literature on hate crime causation frequently acknowledges the possible influence of political rhetoric, and often offers significant qualitative evidence, such as the increased use of epithets such as 'scrounger' in disablist hate crimes (Chakraborti et al. 2014; Garthwaite 2015), while the inflammatory impacts of antecedent events, such as terrorist attacks and contentious political decisions, are widely attested (Disha et al. 2011; Hanes and Machin 2014; King and Sutton 2013; Perry 2014; Williams and Burnap 2016). Despite all this, demonstrating a causal connection between political rhetoric and hate crime has been difficult to pin down. Walters and Brown, in their assessment of hate crime causality, devoted little attention to the impact of rhetoric, bluntly stating that 'demonstrating the causal effects of media or political rhetoric on people's prejudiced attitudes or conduct is fraught with methodological difficulties and few convincing studies exist' (Walters and Brown 2016, p. 27). Even so, given the power of government to indicate an outgroup and politicise social issues, politicians do find themselves in a position of considerable authority.

Efforts have been made to directly link instances of exclusionary rhetoric with increases in hate crimes. Levin (2016) begins his attempt with familiar caveats: that we seldom have data on the time of offences even when we have the dates, that we do not know if offenders actually heard a provocative remark by a political figure, and that it is impossible to know which potential perpetrators have refrained from offending after exposure to a tolerant message. Using official data, Levin highlighted the $2300 \%$ increase in anti-Muslim hate crime in the 111 days after the $9 / 11$ attacks compared with the 111 days before (from four to 96 offences). Dramatic increases in hate crime following antecedent events are well-known, but Levin notes with interest the precipitous drop in daily reported offences following a 
speech from President George W. Bush on the 17th September. In his address, made after conferring with a number of Muslim leaders at the Islamic Center in Washington, DC, Bush emphasised the need for tolerance, stating that:

The face of terror is not the true faith of Islam. That's not what Islam is all about. Islam is peace. These terrorists don't represent peace. They represent evil and war. (Bush 2001 quoted in Levin 2016, p. 29)

Using reported hate crimes collated by the FBI, Levin shows a decline of $66.2 \%$ or $46.7 \%$ in the six days after Bush's speech (depending on whether the division is drawn on the day of the speech or the preceding day, given that we do not know the times of the offences). By UK standards, the figures involved are low. A total of 77 hate crimes were recorded in the six days from 12 September, with 15 on the day of the address. In the six days from the 18th, 26 hate crimes were recorded, including 5 on the 18th itself (Levin 2016). The suddenness of the decrease is nevertheless striking, given the apparent arbitrariness of the date. Levin (2016) found a similar spike following then-Candidate Trump's call for a Muslim travel ban in the aftermath of the San Bernardino mass shooting, with increases corresponding to Trump's comments rather than the attack, while subsequent follow-ups found big rises in the victimisation of Hispanic US citizens following years of demonisation (Levin 2019). While it is true that effective rhetoric reflects established ideas (see Stuckey 2015), the role played in the shaping and directing of sentiment and the setting of the agenda makes it a powerful tool.

Müller and Schwarz (2020) corroborate this notion, finding that Donald Trump's tweets about Islam-related topics were highly correlated with anti-Muslim hate crimes following the announcement of his candidacy, as well as the online discussion and cable news attention devoted to discussion of Islam. Trump's tweets were widely shared by his followers, propagating these sentiments through their networks and driving incidents within the Twitter sphere as well as the wider world. The power to set agendas and direct public sentiment is immense, and separate from the constitutional powers vested in elected leaders (Neustadt 2002). Studies from Oliver (1998) and Oliver et al. (2011) demonstrated this symbolic power, finding that public concern over crime and drug use linked closely with the extent of their foregrounding in presidential addresses over successive decades. Given the power exerted through political rhetoric, the notion that it shapes the content of hate crime discourses is concerning, and examination of the contemporary rhetoric promoted in response to trigger events is a worthwhile pursuit.

This study focuses on the Shamima Begum citizenship furore in the early part of 2019, a high-profile case with clear gendered, racial, and religious aspects that represented a potential hate crime inflection point. Evidence has already emerged that social media postings in the wake of the Begum case corroborate its status as an anti-Muslim hate crime trigger event (Awan et al. 2019). This study intends to indicate the discourses applied to the case by UK politicians in their online rhetoric relating to the case, and ultimately, the role played by political messaging in the circulation of harmful discourses in the aftermath of antecedent hate crime events.

\section{Results and Discussion}

Six out of the nineteen leading politicians evaluated in relation to the Begum case posted tweets related to Shamima Begum over the course of the collection period. Of the sixteen posts published by these six (Diane Abbott [7], Gerard Batten [3], Nigel Farage [3], Jeremy Corbyn [1], Jonathan Bartley [1], and Sian Berry [1]), five are retweets and eleven are individually authored to some extent (i.e., they are a tweet, or a retweet with added comment).

The extent to which many politicians did not pass comment on the Begum case on Twitter is striking. None of the senior government figures captured for this study made any observations on Begum during the featured collection period, including the Prime Minister and Home Secretary. The leaders of the Scottish National Party and Liberal Democrats evidently also saw little merit in wading into the debate, perhaps as the issues strayed 
from their usual remits and offered little obvious upside. Developments in the Shamima Begum saga perhaps did not invoke quite the same sense of shock and grief as lethal terrorist attacks, or the expectation that political leadership should reassure the public (an expectation that led Theresa May and Boris Johnson, unlike other cabinet members, to comment on almost every potential UK terrorist incident that occurred during their premierships throughout this research project). The Begum story was also unusually polarising, and did not perhaps lend itself to harmless platitudes or uncontroversial condemnation in the same way as other trigger events (when sympathy for any victims and appreciation for emergency services offer a simple template for politicians needing to publicly acknowledge an incident).

In any case, commentary on the Begum case was the domain of a limited group of opposition politicians. Labour leader Jeremy Corbyn and Green co-leader Sian Berry restricted themselves to retweeting criticism of the government, while Green co-leader Jonathan Bartley authored one tweet on the topic (Figure 1).

Jonathan Bartley

@jon_bartley

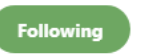

Be angry about Daesh, but be outraged too

by the actions of the Home Secretary who

must now be called to account for his cruel

and brutal decision.

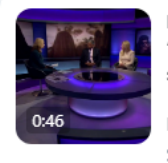

BC Newsnight 0 BBCNewsnight

"There was no attempt to help by the Home Office, I think it's

shocking how the home secretary has treated this situation."

Former Met Police Chief Dal Babu has spoken to the Begum...

Show this thread

6:46 am - 9 Mar 2019

16 Retweets 75 Likes

$Q 2$ tI 16

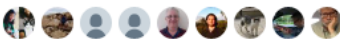

Figure 1. Tweet from Green co-leader Jonathan Bartley, 9 March 2019.

The tone is fierce ('angry ... outraged ... cruel ... brutal'), and the tweet acknowledges both sides of the debate before focusing on condemnation of Sajid Javid. Javid is depicted as heartless and unscrupulous, with an explicit mirroring of the reader's assumed hostility towards the transgressions of IS with disdain for Javid's 'cruel and brutal decision'; the audience is urged to feel outrage, and to support the calling of the Home Secretary 'to account'. This characterisation is unsparing, and similar to the approach adopted by Shadow Home Secretary Diane Abbott, whose five authored tweets on the topic represent the highest volume of commentary from any of the selected politicians (Figures 2-6).

A note on Abbott's particular political positioning is useful here. Abbott became the UK's first black female MP in 1987 (Bunce and Linton 2020), and in recent years, has been a high-profile target of online hate speech. Amnesty found that almost half of all abusive online tweets sent to female MPs in the run up to the 2017 general election were sent to Abbott, and that almost a third of all abusive tweets sampled in the six weeks prior to the election were targeted at her (Dhrodia 2017). This positioning as a prominent black female MP affects how Abbott is viewed by the public and her critics, and is important context when considering her relatively strident use of social media. Again, criticism of the government and her opposite number specifically are the focus of four out of five of these tweets (with the other, Figure 2, targeting the social response to Begum in general). Javid is alleged to have acted 'shamefully' (Figures 4 and 5) and illegally (Figure 3), and the citizenship decision is referred to as 'callous and inhumane' (Figure 3); language reminiscent of Bartley's allusions to 'cruel' and 'brutal' actions (Figure 1). This depiction, irrespective of its validity in this case, reinforces the negative stereotypes of the Conservative Party as uncaring and ruthless that are popular among supporters on the 
left. The Conservative 'brand' has been through many iterations over its lifespan (Pich and Dean 2015), but recent years of austerity are likely to have influenced the perception of the party among the disproportionately young supporters of the Greens or Corbyn-era Labour party (YouGov 2019) and make these characterisations likely to resonate. The juxtaposing of Javid's actions and the suggestion that 'the baby might have lived' (Figure 4) is particularly extreme, while the conspiratorial questioning of the accessibility of the camp (Figure 6) challenges the government's credibility and honesty, and is another attack line echoed extensively in the broader social media response to the Begum story.

Diane Abbott

You might think society had got past blaming groomed young teenagers for their fate. But the attitude towards Shamima Begum is deeply worrying

My piece in @DailyMirror

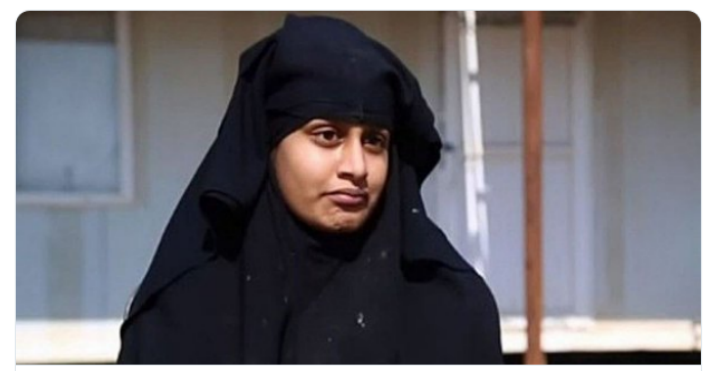

'Shamima Begum is a grooming victim and losing her citizenship due to herit..

EXCLUSIVE Diane Abbott says Sajid Javid is trying to appear tough to help his

leadership ambitions

mirror.co.uk

$8: 25 \mathrm{pm}-21 \mathrm{Feb} 2019$

1,075 Retweets 3,296 Likes

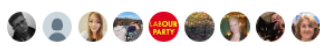

Figure 2. Tweet from Shadow Home Secretary Diane Abbott, 21 February 2019.

Diane Abbott 0

(a) Hackneysbbot

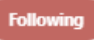

It is against international law to make someone stateless, and now an innocent child has died as a result of a British woman being stripped of her citizenship. This is callous and inhumane

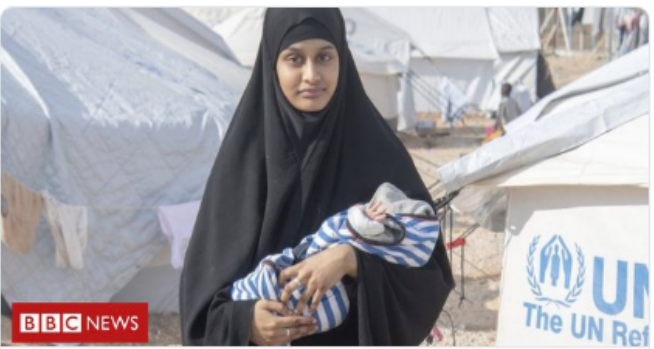

IS bride Shamima Begum's baby dies

The UK government says the death of the weeks-old boy at a Syrian camp is "tragic and deeply distressing"

bbc.co.uk

$7: 40 \mathrm{pm}$ - 8 Mar 2019

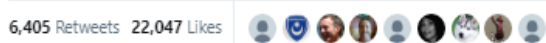

Figure 3. Tweet from Shadow Home Secretary Diane Abbott, 8 March 2019. 
Diane Abbott
WHackneyAbbott

This week a British baby died from pneumonia in a Syrian refugee camp. A tragedy that might have been avoided. If the mother \& baby had been brought home, the mother Shamima Begum would have faced British justice, but the baby might have lived. @sajidjavid has behaved shamefully

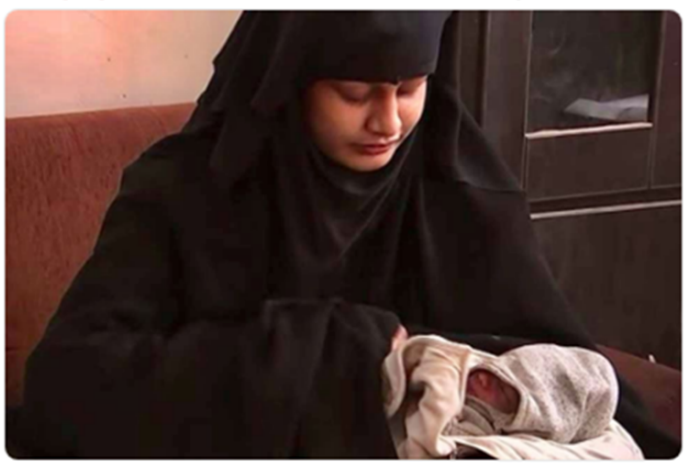

9:00 am - 9 Mar 2019

4,598 Retweets 16,564 Likes 60000000

Figure 4. Tweet from Shadow Home Secretary Diane Abbott, 9 March 2019.

Diane Abbott

(1) HackneyAbbott

"Shamima Begum: baby son dies in Syrian refugee camp" The three week old baby was British. @sajidjavid had a moral responsibility

for the baby. He has behaved shamefully

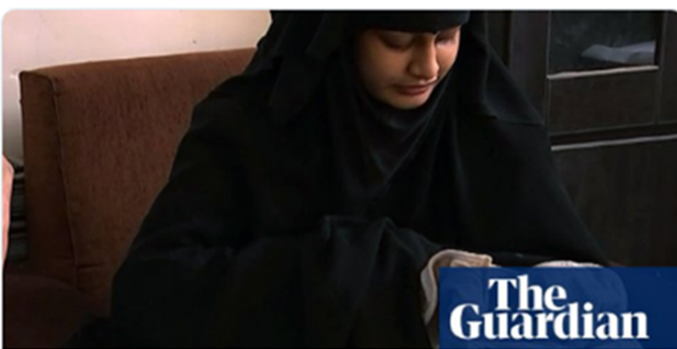

Shamima Begum: baby son dies in Syrian refugee camp

Three-week-old infant is the third child the teenager from east London has lost

theguardian con

$12: 00 \mathrm{pm}$. 9 Mar 2019

927 Retweets 3,161 Likes 영

Figure 5. Tweet from Shadow Home Secretary Diane Abbott, 9 March 2019. 


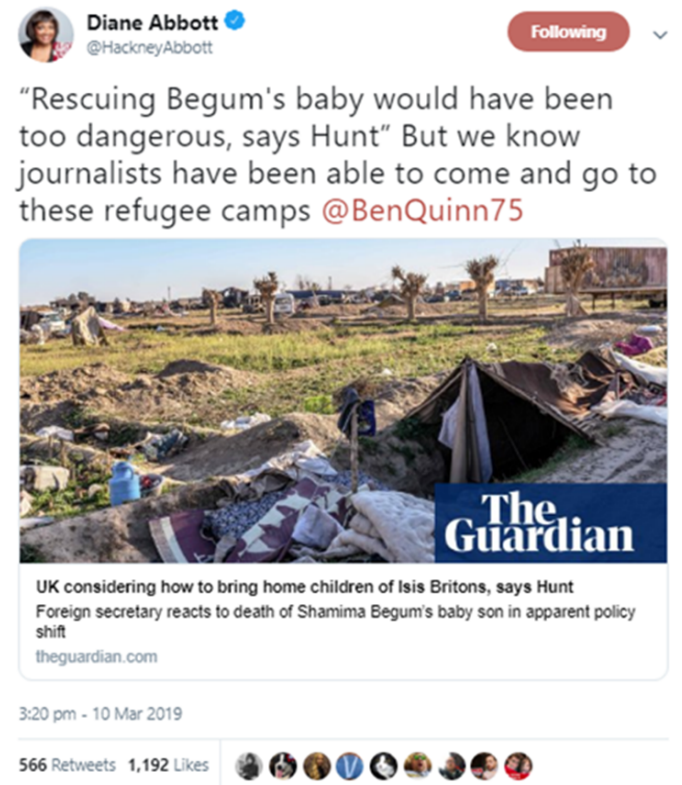

Figure 6. Tweet from Shadow Home Secretary Diane Abbott, 10 March 2019.

Abbott is clearly committed to attacking Javid for his role in the case, particularly in the aftermath of the death of the child, and reticent about expressing much warmth towards Begum herself (a national hate figure, after all). Figure 2 refers to her as a 'groomed young' teenager, but is mostly geared towards criticising the popular backlash. Subsequently, Abbott focuses largely on the death of the 'innocent child' (Figure 3) and the 'three week old baby [who] was British' (Figure 5). The need for Begum to meet consequences is acknowledged in passing, with Abbott noting that 'Shamima Begum would have faced British justice, but the baby might have lived' had she been permitted to return, but the issue is framed around Javid and his culpability. These references to Britishness also serve to pre-empt concerns over Labour's (and Abbott's) national security or patriotic credentials. Corbyn and the party's perceived lack of patriotism, a common attack line, was a constant headache for the Labour party under his leadership (Seabridge 2020) and Abbott's allusions to 'British justice' serve as a way of repackaging an unpopular stance on the citizenship issue. On the whole though, condemnation and questioning of the government appear to be her primary purpose throughout these rhetorical responses, as the Shadow Home Secretary highlights awareness of the Opposition stance and manoeuvres for political advantage.

Abbott and Bartley's language is emotive, then, and fiercely critical of the government response to the Begum case. Then-UKIP leader Gerard Batten and its former leader (and subsequent Brexit Party head) Nigel Farage can be similarly grouped, with the Begum case resonating with their political leanings and both apparently seeing some capital in offering their takes. Batten is known for his preoccupation with Islam, and historically calling for Muslims to sign a special charter renouncing violence and parts of the Qur'an, and for a ban on the building of new mosques in Europe (Mason 2014). He made headlines over the course of his leadership for stating that Islam was a 'death cult', linking Islam to sexual exploitation, and championing policies such as Muslim-only prisons and special security screening for Muslim visitors to the UK (Walker 2018). Unsurprisingly, Batten chose to weigh in on the Shamima Begum case with a number of tweets (Figures 7-9). 


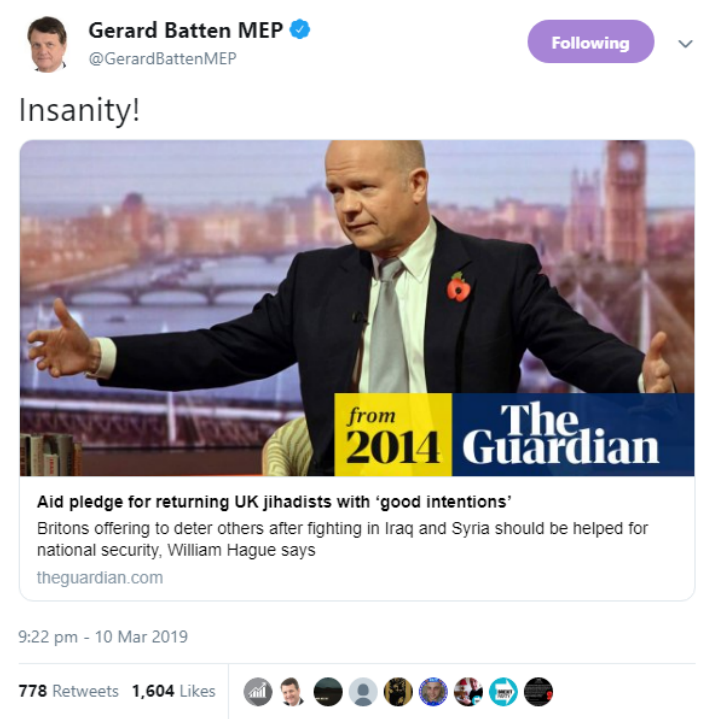

Figure 7. Tweet from UKIP leader Gerard Batten, 10 March 2019.

Gerard Batten MEP

@GerardBattenMEP

Do you remember MSM blanket coverage when Asia Bibi, the persecuted Christian woman from Pakistan was refused asylum because it might offend some Mohammedan cult followers? No neither do I. LBC now as bad as the rest.

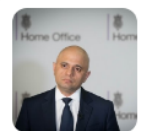

LBC@ @

Following the death of Shamima Begum's three week-old son @NIAbbot asks: how can Sajid Javid's decision to revoke her UK citizenship still be defended?

8:46 am - 11 Mar 2019

1,335 Retweets 2,841 Likes

3.

Figure 8. Tweet from UKIP leader Gerard Batten, 11 March 2019.

Gerard Batten

Good to hear that one of the cult followers confirming what is in their instruction manual. But of course its such a jumble of contradictory nonsense that non-cult members are told they have to be 'scholars' to understand it.

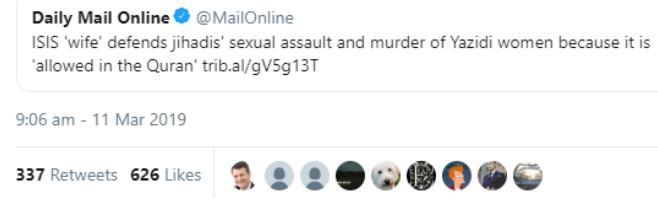

Figure 9. Tweet from UKIP leader Gerard Batten, 11 March 2019.

Two of Batten's three authored tweets (Figures 7 and 9) do not directly mention Begum, but take the form of the retweeting with comment of two old newspaper stories about an unrepentant 'jihadi bride' and the readmission of British citizens who left to join IS respectively. Given that the Begum story was dominating the airwaves at the time, these 
are obviously connected to this case and contribute to the associated discourses. Batten's language is inflammatory, referring to Muslims as 'cult followers' (Figure 8) (the distinction from 'non-cult members' seems to imply that Muslims are the target, rather than jihadists), and their teachings as 'a jumble of contradictory nonsense' (Figure 9). The condemnation of 'scholars' is equally dismissive. The juxtaposition of the Asia Bibi (Christian) case with the Begum (Muslim) case is suggestive of a double standard, as is the misleading analysis that Bibi's asylum case was rejected as 'it might offend some Mohammedan cult followers' (Figure 8) (her application, rightly or wrongly, was turned down due to security concerns and fears about the potential for unrest (Malik 2019)). The reference to 'Insanity!' is attached to a 2014 Guardian report on then-Foreign Secretary William Hague's call for openness to the prospect of rehabilitation for returning jihadists when appropriate (Figure 7). Batten's posting of this old story reads as an attempt to drum up concern about lenient immigration rules facilitating terrorism, with obvious application to the Begum case. The dismissal of LBC and 'the MSM blanket coverage' (Figure 8) is a classic example of the disdain for mainstream media and perception of bias common on the political fringes, particularly on the right (Major 2015), and is a prevalent trope in social media discussion generally and in the wakes of trigger events. 'LBC now as bad as the rest' also nods towards LBC's brand as featuring a diversity of views (Gapper 2019), with Batten seeming to indicate to his sceptical audience that even LBC has now abandoned their perspectives by covering the Begum story so extensively. Batten's rhetoric is uniquely divisive among the featured politicians. All of the responses to the Begum case are critical of their opponents, but Batten's are linked by the relentless dismissal of Islam, and language which stigmatises his opponents as dangerous, irrational, and conspiratorial.

Nigel Farage actually left UKIP due to Batten's 'obsess[ion] with the issue of Islam' (BBC 2018), and his commentary on the Begum case is subtler than his former colleague's. One retweet (of the provocateur Piers Morgan) condemns the linking of Javid's actions with Begum's baby's death (a link repeatedly pushed by Abbott), while his two authored tweets steer clear of the overt hatefulness of Batten's and focus on the political manoeuvrings (Figures 10 and 11).
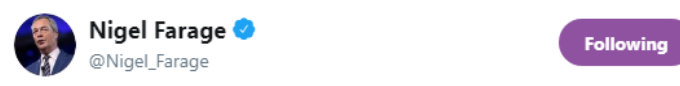

I didn't see this one coming.

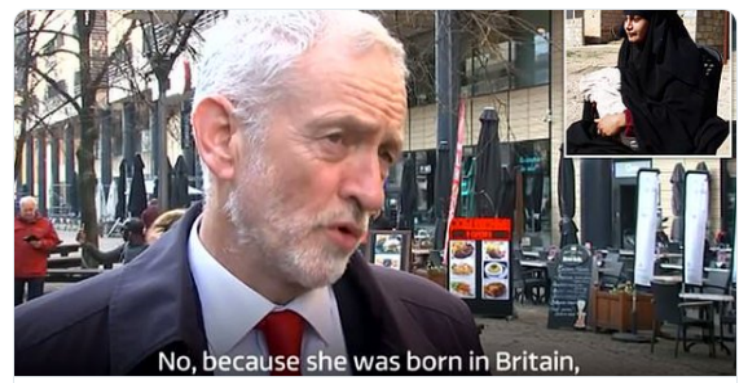

Jeremy Corbyn says Shamima Begum should be let back into Britain

The Labour leader said that the teenager, who gave birth to a baby boy in a refugee

camp on Sunday, had 'a right to return' after fleeing the country to support IS.

dailymail.co.uk

$2: 17 \mathrm{pm}-21 \mathrm{Feb} 2019$

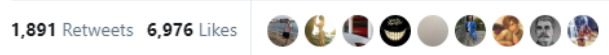

Figure 10. Tweet from Brexit Party leader Nigel Farage, 21 February 2019. 


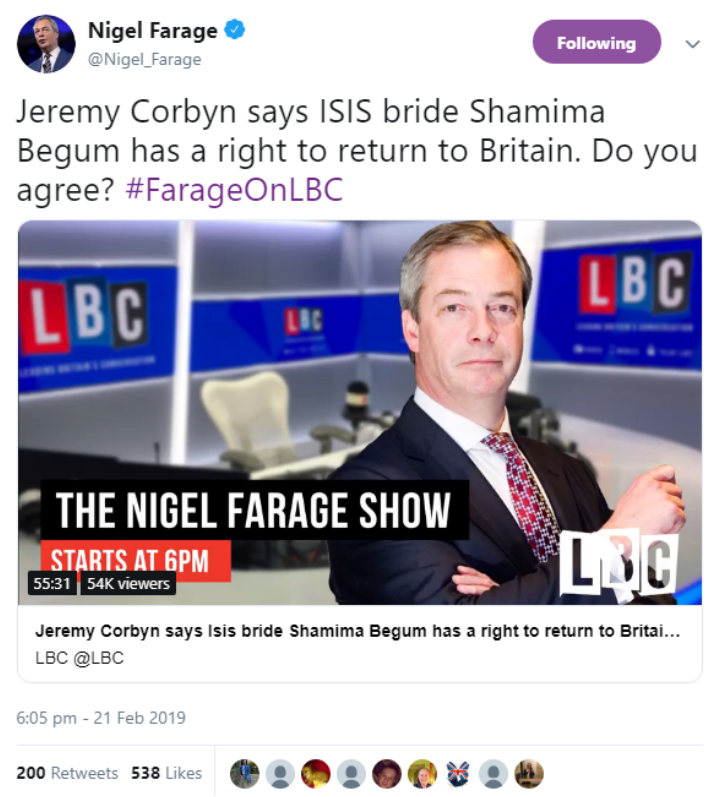

Figure 11. Tweet from Brexit Party leader Nigel Farage, 21 February 2019.

Figure 10, retweeting a Daily Mail article on Corbyn's objections to the Home Office citizenship decision, is humorously understated and winks towards the aforementioned stereotype of Corbyn as anti-British, or soft on national security issues, in a way likely to appeal to Farage's followers. Indeed, Abbott's undercurrent of patriotism can be read as a warding off of just this kind of caricature. Figure 11, promoting Farage's talk show on LBC, uses the evocative phrase 'ISIS bride', dangling the bait of Corbyn's controversial stance, and innocently asking Farage's followers if they agree. The wording is relatively neutral, but the context and choice of angle taken in the post can be seen as an attempt to whip up debate (reasonably enough, given that it is advertising Farage's call-in radio programme). ISIS or jihadi 'bride', terms seen extensively throughout the coverage and commentary on the Begum case, serves to marginalise female agency in terrorism and incorporate radical female political action into gendered discourses (Martini 2018). On this level, Farage's activity can be viewed as propagating a negative narrative, although a dishearteningly ubiquitous one.

The differences between Batten and Farage are interesting, and thrown into relief by their responses to the Begum story. Farage's fame and following derive largely from his years as the leader of UKIP, and the anti-European, radical right party attracted frequent criticism that the followers, personnel, and platform of UKIP encouraged racism. Unlike Batten, Farage was careful over that time to publicly renounce racism, and pushing the UKIP platform as inclusive while reaping the benefits of racist sentiment and the outsider positioning that criticism lent him. The EU referendum campaign's notorious Breaking Point poster is an excellent example of that balancing act, and the benefits of anti-racist outrage in promoting a populist message and motivating voters (Durrheim et al. 2018). Farage is an able politician, and rallied massive support for his party and his cause, exploiting racist animus and preserving deniability for his members and voters. The decline of UKIP under Batten's tenure, with the party's vote share and membership numbers collapsing, has been linked in large part to the perception of a veer to the hard right, supported by the public statements of its departing officials and Batten's high-profile championing of toxic far-right activists, such as Tommy Robinson, or defence of his candidate's rape jokes (BBC 2019a). The differences between Batten and Farage's Shamima Begum posts are instructive, with Farage able to appeal to his constituency and chime in on this resonant issue without the toxicity of Batten's approach and its limited mainstream appeal. Farage's posts avoid this morass and capitalise on the political angle. Just as UKIP won the 2014 European Parliament election under his leadership, Farage's Brexit Party managed to win 
the 2019 European election six weeks after its launch, while Gerard Batten lost his seat in the European Parliament (Stone 2019).

\section{Conclusions}

This study identifies a number of key discourses of a sample of UK political rhetoric issued online in response to the Shamima Begum case, highlighting the political focuses and attacks lines used by politicians from opposite ends of the political spectrum in response to a prominent potential Islamophobic antecedent hate crime event. It demonstrates the variations in the volume and quality of content contributed by different politicians to developments in a terrorism-related case with clear religious and racial elements, with right-wing commentators focusing more on Begum herself and the crimes of IS, while leftwing politicians, such as Bartley and Abbott, focus largely on criticism of the government and the perceived callousness of the citizenship decision. On an individual level, there are significant differences in tone, with the overt Islamophobia of UKIP leader Gerard Batten marking a contrast from the relative restraint of his predecessor Nigel Farage (who innocently appeals for the public's thoughts on the Begum case and ridicules Jeremy Corbyn). These differences reflect individual politicians' roles and outlooks, and break along political faultlines as their sources cultivate different audiences. Ultimately, condemning Islam in bitter tones and questioning the humanity of a government minister are both rhetorical contributions which heighten tensions and feed division, irrespective of the relative merits of their cases and wider imbalances in the cultural and media ecosystem. The potential for racially and religiously aggravating rhetoric about Begum to influence the victimisation of Muslims, by promoting narratives of danger and untrustworthiness, nonetheless make it a topic of particular significance given the routine and growing nature of Islamophobic hate crime (Home Office 2020). Alongside these themes, the lack of commentary from leading ministers on this high-profile news story is striking, and at odds with the outpourings that frequently accompany other trigger events (such as lethal terrorist attacks), presumably due to perceptions that there is limited political capital available in such a divisive case. These audience and context considerations are key to understanding how rhetoric is employed and, thus, its intended and likely impact in the aftermath of divisive events in relation to social division and hate crime.

This paper has focused on the rhetorical contributions of politicians to the online milieu that cultivates and distributes hate speech, and examined how rhetoric characterises the trigger event involved and which readings are promoted. Future work will explore the hate speech discourses in the wider online response to the Begum case, a complementary strand of this research, and their association with the themes promoted in the rhetoric. Exploring the applicability of these themes to the rhetoric applied to other trigger events, particularly where the gendered, racial, and religious aspects of the Begum case differ, would be a useful next step to develop understandings in this area. In a context of generalised public concern with the impacts of inflammatory rhetoric and the role of social media in promoting disinformation and hate speech, this research offers a useful examination of how political messaging may be associated with online hate speech in the aftermath of a high-profile UK trigger event.

Funding: This research received no external funding.

Institutional Review Board Statement: The study was conducted according to the guidelines of the Declaration of Helsinki, and approved by the Institutional Review Board (or Ethics Committee) of the University of Leicester (date of approval: 4 December 2018).

Informed Consent Statement: Not applicable.

Data Availability Statement: The data presented in this study are openly available on Twitter, or appropriate Twitter archives.

Conflicts of Interest: The author declares no conflict of interest. 


\section{References}

All Party Parliamentary Group on Social Integration. 2017. Integration Not Demonisation. Available online: http://d3n8a8pro7 vhmx.cloudfront.net/themes/570513f1b504f500db000001/attachments/original/1504379228/TC0016_AAPG_Integration_ not_Demonisation_Report.pdf?1504379228 (accessed on 14 December 2020).

Awan, Imran, Hollie Sutch, and Pelham Carter. 2019. Extremism Online-Analysis of Extremist Material on Social Media. Available online: https:/ /assets.publishing.service.gov.uk/government/uploads/system/uploads/attachment_data/file/821874/AwanSutch-Carter-Extremism-Online.pdf (accessed on 14 December 2020).

Balica, Raluca. 2017. The Criminalization of Online Hate Speech: It's Complicated. Contemporary Readings in Law and Social Justice 9: 184-90.

BBC. 2015. Missing Teenagers Have Crossed into Syria, Met Police Say. Available online: https://www.bbc.co.uk/news/uk-31612666 (accessed on 13 January 2020).

BBC. 2018. Former Leader Nigel Farage Quits UKIP. Available online: https:/ /www.bbc.co.uk/news/uk-politics-46448299 (accessed on 2 March 2020).

BBC. 2019a. From Farage to Batten: What Happened to UKIP's Class of 2014? Available online: https://www.bbc.co.uk/news/ukpolitics-47934021 (accessed on 2 March 2020).

BBC. 2019b. Shamima Begum: Ex-Bethnal Green Schoolgirl Who Jointed IS 'Wants to Come Home'. Available online: https: //www.bbc.co.uk/news/uk-47229181 (accessed on 13 January 2020).

Bienkov, Adam. 2019. There Was a Spike in Hate Crimes against Muslims after Boris Johnson Compared Women Wearing Burqas to 'Letterboxes' and 'Bank Robbers'. Available online: https:/ / www.businessinsider.com/spike-hate-crimes-against-muslims-borisjohnson-women-burqa-letterboxes-2019-9?r=US\&IR=T (accessed on 16 October 2020).

Blalock, Hubert M. 1960. A Power Analysis of Racial Discrimination. Social Forces 39: 53-59. [CrossRef]

Briant, Emma, Nick Watson, and Gregory Philo. 2013. Reporting disability in the age of austerity: The changing face of media representation of disability and disabled people in the United Kingdom and the creation of new "folk devils". Disability $\mathcal{E}$ Society 28: 874-89.

Brown, Alexander. 2017. What is hate speech? Part 1: The Myth of Hate. Law and Philosophy 36: 72-91. [CrossRef]

Bunce, Robin, and Samara Linton. 2020. How Diane Abbott Fought Racism-And Her Own Party-To Become Britain's First Black Female MP. Available online: https: / www.theguardian.com/politics/2020/sep/29/how-diane-abbott-fought-racism-and-herown-party-to-become-britains-first-black-female-mp (accessed on 21 June 2021).

Burnett, Jon. 2017. Racial violence and the Brexit state. Race \& Class 58: 85-97.

Carr, Harry. 2019. Shamima Begum: 78\% of Britons Support Revoking IS Bride's UK Citizenship—Sky Data Poll. Available online: https:/ / news.sky.com/story/shamima-begum-78-of-britons-support-revoking-is-brides-uk-citizenship-sky-data-poll11643068 (accessed on 16 January 2020).

Chakraborti, Neil, and Jon Garland. 2015. Hate Crime: Impact, Causes and Responses. London: Sage.

Chakraborti, Neil, Jon Garland, and Stevie-Jade Hardy. 2014. The Leicester Hate Crime Project: Findings and Conclusions. Leicester: University of Leicester.

Conger, Kate, and Mike Isaac. 2021. Twitter Permanently Bans Trump, Caping Online Revolt. Available online: https://www.nytimes. com/2021/01/08/technology/twitter-trump-suspended.html (accessed on 12 February 2021).

Dejevsky, Mary. 2019. Four Years Ago I Argued the UK Should Make No Effort to Retrieve Shamima Begum from Isis-I Stand by That Today. Available online: https:/ / www.independent.co.uk/voices/shamima-begum-isis-syria-raqqa-bethnal-green-ukgovernment-a8779401.html (accessed on 16 January 2020).

Devine, Daniel. 2021. Discrete Events and Hate Crimes: The Causal Role of the Brexit Referendum. Social Science Quarterly 102: 374-86. [CrossRef]

Dhrodia, Azmina. 2017. Unsocial Media: Tracking Twitter Abuse against Women MPs. Available online: https://medium.com/ @AmnestyInsights/unsocial-media-tracking-twitter-abuse-against-women-mps-fc28aeca498a (accessed on 21 June 2021).

Disha, Ilir, James C. Cavendish, and Ryan D. King. 2011. Historical Events and Spaces of Hate: Hate Crimes against Arabs and Muslims in Post-9/11 America. Social Problems 58: 21-46. [CrossRef]

Doward, Jamie, Mark Townsend, and Nosheen Iqbal. 2019. Shamima Begum: Sajid Javid labelled 'Moral Coward' over Baby Death. Available online: https:/ / www.theguardian.com/uk-news/2019/mar/09/sajid-javid-moral-coward-death-begum-baby (accessed on 13 January 2020).

Durrheim, Kevin, Mukadder Okuyan, Michelle Sinayobye Twali, Efrain García-Sánchez, Adrienne Pereira, Jennie Sofia Portice, Tamara Gur, Ori Wiener-Blotner, and Tina F. Keil. 2018. How racism discourse can mobilize right-wing populism: The construction of identity and alliance in reactions to UKIP's Brexit "Breaking Point" campaign. Journal of Community and Applied Social Psychology 28: 385-405. [CrossRef]

Gagliardone, Iginio, Danit Gal, Thiago Alves, and Gabriela Martinez. 2015. Countering Online Hate Speech. Paris: United Nations Educational, Scientific and Cultural Organisation.

Gapper, John. 2019. How LBC Broke All the Rules-And Captured the Political Zeitgeist. Available online: https://www.ft.com/ content/64b04cdc-1ad9-11ea-97df-cc63de1d73f4 (accessed on 22 June 2021).

Garthwaite, Kayleigh. 2015. "Keeping meself to meself" - How Social Networks Can Influence Narratives of Stigma and Identity for Long-term Sickness Benefits Recipients. Social Policy \& Administration 49: 199-212. 
Gelber, Katherine, and Luke McNamara. 2016. Evidencing the harms of hate speech. Social Identities 22: 324-41. [CrossRef]

Glaeser, Edward L. 2005. The political economy of hatred. Quarterly Journal of Economics 120: 45-86.

Hanes, Emma, and Stephen Machin. 2014. Hate Crime in the Wake of Terror Attacks: Evidence from 7/7 and 9/11. Journal of Contemporary Criminal Justice 30: 247-67. [CrossRef]

Healy, Jane C. 2020. 'It spreads like a creeping disease': Experiences of victims of disability hate crimes in austerity Britain. Disability $\mathcal{E}$ Society 35: 176-200.

Hern, Alex. 2020. Chief Rabbi Accuses Facebook and Twitter of Complicity in Antisemitism. Available online: https://www. theguardian.com/news/2020/jul/27/chief-rabbi-facebook-twitter-antisemitism-complicity-wiley (accessed on 16 October 2020).

Home Office. 2020. Hate Crime, England and Wales, 2019 to 2020. Available online: https:/ /www.gov.uk/government/statistics/hatecrime-england-and-wales-2019-to-2020/hate-crime-england-and-wales-2019-to-2020\#annex--provisional-trends-in-raciallyor-religiously-aggravated-offences-to-july-2020-under-covid-19-restrictions (accessed on 4 August 2021).

Jungherr, Andreas. 2016. Twitter use in election campaigns: A systematic literature review. Journal of Information Technology E Politics 13: 72-91.

Kelion, Leo. 2020. Facebook and Twitter Grilled over US Election Actions. Available online: https://www.bbc.co.uk/news/education54974819 (accessed on 24 November 2020).

King, Ryan D., and Gretchen M. Sutton. 2013. High Times for Hate Crimes: Explaining the Temporal Clustering of Hate-Motivated Offending. Criminology 51: 871-94. [CrossRef]

Knudsen, Rachel Ahern. 2014. Homeric Speech and the Origins of Rhetoric. Baltimore: John Hopkins.

Levin, Brian. 2016. Special Status Report: Hate Crime in the United States. San Bernardino: California State University.

Levin, Sam. 2019. Violent Hate Crimes in US Reach Highest Level in 16 Years, FBI Reports. Available online: https:/ /www.theguardian. com/society/2019/nov/12/hate-crimes-2018-latinos-transgender-fbi (accessed on 14 December 2020).

Lewis, Clara S. 2013. Tough on Hate? The Cultural Politics of Hate Crimes. London: Rutgers University Press.

Major, Mark. 2015. Conservative Consciousness and the Press: The Institutional Contribution to the Idea of the 'Liberal Media' in Right-Wing Discourse. Critical Sociology 41: 483-91. [CrossRef]

Malik, Nikita. 2019. The UK Should Be Ashamed It Could Not Offer Asia Bibi Asylum. Available online: https://www.forbes.com/ sites/nikitamalik/2019/05/09/the-uk-should-be-ashamed-it-could-not-offer-asia-bibi-asylum/\#1c85fc9b3000 (accessed on 2 March 2020).

Martini, Alice. 2018. Making women terrorists into "Jihadi brides": An analysis of media narratives on women joining ISIS. Critical Studies on Terrorism 11: 458-77. [CrossRef]

Mason, Rowena. 2014. Ukip MEP Says British Muslims Should Sign Charter Rejecting Violence. Available online: https://www. theguardian.com/politics/2014/feb/04/ukip-mep-gerard-batten-muslims-sign-charter-rejecting-violence (accessed on 15 December 2020).

McDevitt, Jack, Jack Levin, and Susan Bennett. 2002. Hate Crime Offenders: An Expanded Typology. Journal of Social Issues 58: 303-17. [CrossRef]

Morgan, Piers. 2019. PIERS MORGAN: Don't Let These Women Wedded to Terror Come Home-They Made Their ISIS Husbands' Beds, Now Let Them Rot in Hell in Them. Available online: https:/ /www.dailymail.co.uk/columnists/article-6718019/Dont-letwomen-wedded-terror-come-home.html (accessed on 16 January 2020).

Müller, Karsten, and Carlo Schwarz. 2020. From Hashtag to Hate Crime: Twitter and Anti-Minority Sentiment. SSRN, 1-47. [CrossRef]

Neustadt, Richard E. 2002. Presidential power and the research agenda. Presidential Studies Quarterly 32: 720-23. [CrossRef]

Novet, Jordan. 2021. Parler's De-Platforming Shows the Exceptional Power of Cloud Providers Like Amazon. Available online: https: / / www.cnbc.com/2021/01/16/how-parler-deplatforming-shows-power-of-cloud-providers.html (accessed on 12 February 2021).

O'Neill, Aoife. 2017. Hate Crime, England and Wales, 2016/17. London: Home Office.

Oliver, Willard M. 1998. Presidential Rhetoric on Crime and Public Opinion. Criminal Justice Review 23: 139-60. [CrossRef]

Oliver, Willard M., Joshua Hill, and Nancy E. Marion. 2011. When the President Speaks ... : An Analysis of Presidential Influence Over Public Opinion Concerning the War on Drugs. Criminal Justice Review 36: 456-69. [CrossRef]

Parmelee, John H., and Shannon L. Bichard. 2012. Politics and the Twitter Revolution: How Tweets Influence the Relationship between Political Leaders and the Public. Plymouth: Lexington Books.

Perry, Barbara. 2001. In the Name of Hate: Understanding Hate Crimes. London: Routledge.

Perry, Barbara. 2014. Gendered Islamophobia: Hate crime against Muslim women. Social Identities 20: 74-89. [CrossRef]

Perry, Barbara, and Ryan Scrivens. 2018. A Climate for Hate? An Exploration of the Right-Wing Extremist Landscape in Canada. Critical Criminology 26: 169-87. [CrossRef]

Piatkowska, Sylwia J., and Brian J. Stults. 2021. Brexit, Terrorist Attacks, and Hate Crime: A Longitudinal Analysis. Social Problems, 1-29. [CrossRef]

Piatkowska, Sylwia J., Andreas Hövermann, and Tse-Chuan Yang. 2020. Immigration Influx as a Trigger for Right-Wing Crime: A Temporal Analysis of Hate Crimes in Germany in the Light of the 'Refugee Crisis'. British Journal of Criminology 60: 620-41. [CrossRef]

Pich, Christopher, and Dianne Dean. 2015. Political branding: Sense of identity or identity crisis? An investigation of the transfer potential of the brand identity prism to the UK Conservative Party. Journal of Marketing Management 31: 1353-78. [CrossRef] 
Quarmby, Katharine. 2012. Media reporting and disability hate crime. In Disability, Hate Crime and Violence. Edited by Alan Roulstone and Hannah Mason-Bish. Abingdon: Routledge, pp. 64-79.

Seabridge, James. 2020. Labour's Patriotic Problem. Available online: https://www.politics.co.uk/comment-analysis/2020/12/14 /labour-s-patriotic-problem/ (accessed on 26 May 2021).

Sherlock, Ruth, Joe Daunt, and Sam Tarling. 2015. Found: The Bethnal Green Schoolgirls Who Ran away to Syria. Available online: https:/ / www.telegraph.co.uk/news/2016/03/18/found-the-bethnal-green-schoolgirls-who-ran-away-to-syria/ (accessed on 13 January 2020).

Stone, Jon. 2019. European Election Results: UKIP Leader Gerard Batten Loses His Seat. Available online: https:/ / www.independent. co.uk/news/uk/politics/european-election-results-ukip-eu-eu-latest-gerard-batten-a8931376.html (accessed on 2 March 2020).

Stuckey, Mary E. 2015. Political Rhetoric: A Presidential Briefing Book. Piscataway: Transaction Publishers.

Trump, D. 2019. July 14. Available online: https:/ / twitter.com/realDonaldTrump/status/1150381395078000643 (accessed on 16 October 2020).

Van Kesteren, John. 2016. Assessing the risk and prevalence of hate crime victimization in Western Europe. International Review of Victimology 22: 139-60. [CrossRef]

Waldron, Jeremy. 2012. The Harm in Hate Speech. London: Harvard University Press.

Walker, Peter. 2018. Gerard Batten Drags Ukip Further Right with Harsh Anti-Islam Agenda. Available online: https://www. theguardian.com/politics/2018/sep/21/gerard-batten-drags-ukip-further-right-with-harsh-anti-islam-agenda (accessed on 2 March 2020).

Wallis, Lynne. 2019. Shamima Begum Was the Victim of a Cult—She Needs Help. Available online: https:/ / www.theguardian.com/ commentisfree/2019/mar/11/shamima-begum-cult-victim-isis (accessed on 16 January 2020).

Walters, Mark Austin. 2011. A General Theories of Hate Crime? Strain, Doing Difference and Self Control. Critical Criminology 19: 313-30. [CrossRef]

Walters, Mark Austin, and Rupert Brown. 2016. Causes and Motivations of Hate Crime. Equality and Human Rights Commission Research Report 102. Manchester: EHRC.

Williams, Matthew L., and Pete Burnap. 2016. Cyberhate on Social Media in the aftermath of Woolwich: A Case Study in Computational Criminology and Big Data. British Journal of Criminology 56: 211-38. [CrossRef]

Williams, Matthew L., Pete Burnap, Amir Javed, Han Liu, and Sefa Ozalp. 2020. Hate in the Machine: Anti-Black and Anti-Muslim Social Media Posts as Predictors of Offline Racially and Religiously Aggravated Crime. The British Journal of Criminology 60: 93-117. [CrossRef]

YouGov. 2019. 2019 General Election: The Demographics Dividing Britain. Available online: https://yougov.co.uk/topics/politics/ articles-reports /2019/10/31/2019-general-election-demographics-dividing-britai (accessed on 15 December 2020). 